Article

\title{
COVID-19 and the Dynamics of Distance in International Business
}

\author{
Christine Côté ${ }^{1}$, Saul Estrin ${ }^{1}$, Klaus E. Meyer ${ }^{2}$, Daniel Shapiro ${ }^{3}$ \\ ${ }^{1}$ London School of Economics, UK, ${ }^{2}$ Ivey Business School, Canada, ${ }^{3}$ Simon Fraser University, Canada \\ Keywords: international travel, covid-19, cage framework, international business, distance \\ https://doi.org/10.46697/001c.18080
}

\section{AIB Insights}

Vol. 20, Issue 3, 2020

Distance is a central concept in the teaching of international business (IB). However, most textbooks treat distance as static or slowly changing. We argue that distance is inherently a dynamic construct, as highlighted by the impact of COVID-19 on international business activities. Using the popular CAGE framework as a baseline, we illustrate the implications of distance being dynamic by introducing likely effects of COVID-19 on distance, and by discussing in depth barriers to the movement of people as an important aspect of distance. We conclude with implications for the application of distance in corporate decision making and international business teaching.

\section{DISTANCE IN INTERNATIONAL BUSINESS}

International business scholarship recognized distance as a key construct influencing location choice, entry mode, and post-entry strategy. The IB literature has explored many aspects of distance and their impacts on international business (Kostova et al., 2020). Most textbooks and scholarly studies analyse distance as slow changing or static. Others assume that important aspects of distance are gradually diminishing due to technological progress and the liberalization of trade and investment regimes. A popular approach integrating much of this literature is the CAGE framework initially proposed by Ghemawat (2001), whereby the multiple aspects of distance are considered in four dimensions, as described in Table 1. COVID-19 and policy responses to the pandemic have disrupted many of these aspects, thus highlighting that distance is not stable. ${ }^{1}$

The immediate (short run) effects of COVID-19 became evident in Spring 2020 when governments reacted to the spread of the virus. The effect on international business were sharp: according to UNCTAD's Global Investment Trend Monitor, Foreign Direct Investment flows fell by $49 \%$ in the first half of 2020, especially flows into Europe and North America.

The longer run effects are harder to predict, and may interact with pre-existing trends. Thus, the pandemic is likely to accelerate the use of communication technologies, robotics, and artificial intelligence, which would reduce distance for some types of cooperation and knowledge sharing within and between organizations. For example, Brynjolfsson, Hui, \& Liu (2018) show that speech recognition technology increased eBay sales in Latin America, one of the many processes likely to be employed more intensively during and after COVID-19. At the same time, the pandemic is inducing policymakers to raise certain barriers to trade, investment, or the movement of people, be it to combat the virus or to appease nationalist or populist political groups.

Table 1 provides a more systematic set of examples of immediate effects of COVID-19 for each of the CAGE dimensions, along with predictions of possible longer-term effects. It is clear that the short-run effects have been to increase "distance." In particular, cultural differences regarding public health and vaccines; increased political distance; increased restrictions on movements of people; and differential economic impacts of the pandemic work to increase distance and therefore limit many aspects of international business. The longer-term effects are uncertain and depend on the persistence, and possible acceleration of short-run effects, and the degree to which these can be offset, particularly by accelerated technological change.

Moreover, these effects can be interactive, so that even incremental changes in one element of the CAGE may combine with other elements with a resultant major effect on international business. For example, if cultural norms toward public health (such as resistance to vaccination) extend the pandemic and limit economic recovery in a country, that will likely affect economic distance (as some countries recover faster), and administrative distance (as restrictions on movements of people from those countries persist, perhaps increasing political tensions between them). At the same time, COVID-19 may accelerate the adoption of technologies, notably digital communications, and e-business technologies, that reduce the costs of distance; for example the dramatic increase in online learning at school and universities, introduced initially to facilitate education through the pandemic has the potential to transform the business model of education internationally.

To further illustrate our argument about the dynamic and interactive nature of distance effects, we focus on a specific example of a sudden change brought about by the pandemic, namely the impact of travel restrictions on international business.

\section{THE CASE OF TRAVEL BARRIERS}

Changes in administrative distance, such as rapidly im- 
Table 1: Likely Impact of COVID-19 on CAGE Dimensions of Distance

\begin{tabular}{|c|c|c|c|}
\hline Distance & Examples & Short-Run Impact & Possible Long-Run Impact \\
\hline $\begin{array}{l}\text { Cultural } \\
\text { (includes } \\
\text { differences in } \\
\text { informal } \\
\text { institutions, } \\
\text { such as } \\
\text { attitudes, } \\
\text { values and } \\
\text { norms) }\end{array}$ & $\begin{array}{l}\text { Attitudes towards } \\
\text { individual benefits } \\
\text { versus risk created } \\
\text { for others in the } \\
\text { community. } \\
\text { Attitudes towards } \\
\text { public health } \\
\text { policies such as } \\
\text { social distancing and } \\
\text { vaccination. }\end{array}$ & $\begin{array}{l}\text { Differences in attitudes to safety } \\
\text { standards likely affect the } \\
\text { persistence of the pandemic. Higher } \\
\text { infection rates arising in } \\
\text { consequence likely deter inward } \\
\text { travel from countries with low } \\
\text { infection rates. This would affect } \\
\text { notably tourism and education } \\
\text { sectors. }\end{array}$ & $\begin{array}{l}\text { If vaccinations are resisted by a } \\
\text { significant share of the population, "herd } \\
\text { immunity" becomes difficult to achieve } \\
\text { and COVID-19 may persist in those } \\
\text { countries, possibly resulting in further } \\
\text { travel and trade restrictions. } \\
\text { Students from China (a low infection } \\
\text { country in summer 2020) are less likely } \\
\text { to go to countries with high infection } \\
\text { rates, such as the USA, with long-run } \\
\text { impact on human capital formation in } \\
\text { both countries. }\end{array}$ \\
\hline $\begin{array}{l}\text { Administrative } \\
\text { (includes } \\
\text { differences in } \\
\text { regulatory } \\
\text { institutions, } \\
\text { membership in } \\
\text { supranational } \\
\text { institutions } \\
\text { and bilateral } \\
\text { political } \\
\text { relationships) }\end{array}$ & $\begin{array}{l}\text { National regulation } \\
\text { requiring local } \\
\text { production of } \\
\text { medicines and } \\
\text { medical equipment } \\
\text { and/or restricting } \\
\text { the export of such } \\
\text { products (UNCTAD, } \\
\text { 2020). } \\
\text { Increased } \\
\text { competition among } \\
\text { countries for access } \\
\text { to medical products } \\
\text { may increase the } \\
\text { importance of } \\
\text { political distance } \\
\text { and reduce trust in } \\
\text { multilateral } \\
\text { institutions (like } \\
\text { WHO) to provide } \\
\text { solutions }\end{array}$ & $\begin{array}{l}\text { Increases in administrative barriers } \\
\text { related to medical products reduce } \\
\text { trade in such products, and may } \\
\text { disrupt existing global value chains } \\
\text { (UNCTAD, 2020). Such barriers have } \\
\text { arisen, even between countries that } \\
\text { would normally be considered } \\
\text { politically similar, such as the EU. } \\
\text { Political tensions and lack of } \\
\text { intergovernmental trust arguably } \\
\text { inhibited information regarding the } \\
\text { pandemic, or its reception in other } \\
\text { countries, thus slowing down policy } \\
\text { responses to the pandemic. } \\
\text { Political affinity, even at sub-national } \\
\text { level, in some cases facilitated trade } \\
\text { in medical goods. }\end{array}$ & $\begin{array}{l}\text { Trade barriers for medical products may } \\
\text { persist, may spill over to other sectors, } \\
\text { and trigger retaliatory policies by } \\
\text { (former) trade partners. At firm level, } \\
\text { more geographically restricted sourcing } \\
\text { likely reduces supply chain resilience } \\
\text { (Gereffi, 2020) but may also accelerate } \\
\text { the adoption of new technologies such } \\
\text { as robotics or artificial intelligence. } \\
\text { As bilateral agreements become more } \\
\text { important relative to multilateral } \\
\text { agreements, trust and familiarity with } \\
\text { the partner country's political system } \\
\text { becomes more important, making } \\
\text { political distance more important. } \\
\text { Location decisions for foreign investors } \\
\text { become more complex. }\end{array}$ \\
\hline $\begin{array}{l}\text { Geographic } \\
\text { (includes } \\
\text { physical } \\
\text { distance and } \\
\text { infrastructure } \\
\text { facilitating } \\
\text { movement of } \\
\text { goods and } \\
\text { people, such } \\
\text { as ports and } \\
\text { airports) }\end{array}$ & $\begin{array}{l}\text { Restrictions on } \\
\text { travel and } \\
\text { movement of people } \\
\text { limit international } \\
\text { transactions based } \\
\text { on face to face } \\
\text { interactions. }\end{array}$ & $\begin{array}{l}\text { Restrictions on travel immediately } \\
\text { affected tourism and education } \\
\text { related travel, but also trade in } \\
\text { goods depending on supplementary } \\
\text { services. In contrast, digital services } \\
\text { grew, often as a substitute to other } \\
\text { forms. }\end{array}$ & $\begin{array}{l}\text { Many travel barriers are likely } \\
\text { temporary, but lasting effects likely } \\
\text { include increased familiarity with digital } \\
\text { technologies that can substitute for } \\
\text { travel, and reduced numbers of } \\
\text { international students. }\end{array}$ \\
\hline $\begin{array}{l}\text { Economic } \\
\text { (includes key } \\
\text { economic } \\
\text { variables such } \\
\text { as level of } \\
\text { development, } \\
\text { size of the } \\
\text { economy } \\
\text { (GDP), and } \\
\text { income } \\
\text { distribution). }\end{array}$ & $\begin{array}{l}\text { The economic } \\
\text { impact of the } \\
\text { pandemic varies } \\
\text { across countries in } \\
\text { terms of, e.g., depth } \\
\text { of the recession and } \\
\text { increase of } \\
\text { inequality. }\end{array}$ & $\begin{array}{l}\text { The recession reduces GDP and } \\
\text { trade, with deeper declines in } \\
\text { countries with prolonged spread of } \\
\text { COVID-19. While some argue that } \\
\text { the least developed economies will } \\
\text { be the most strongly impacted, the } \\
\text { relatively fast response of China and } \\
\text { the relatively slow response in the } \\
\text { US suggests the issue is more } \\
\text { complex. }\end{array}$ & $\begin{array}{l}\text { The differential economic impact is } \\
\text { likely to have a lasting effect and may } \\
\text { even widen as some countries, possibly } \\
\text { the poorest, will be slower to recover } \\
\text { and will be disadvantaged in accessing } \\
\text { vaccines if and when they become } \\
\text { available (Reinhart \& Reinhart, 2020). } \\
\text { As economic distance changes, perhaps } \\
\text { rapidly, location decisions become more } \\
\text { complex. Strength of health systems } \\
\text { becomes an important factor. }\end{array}$ \\
\hline
\end{tabular}

posed travel restrictions, affect international business in different industries in profoundly different ways. At the height of the pandemic in April 2020, flights were cancelled, and travellers often had to undergo quarantine for the incubation period of the virus (two weeks) before being able to move freely in the country of arrival. However, travel restrictions between pairs of countries have taken many different forms and have varied greatly in severity and impact. Looking forward, we suggest that at least in some countries, some forms of travel restrictions will likely remain for much longer. Examples include time-consuming health checks on arrival, taxes on air travel (or price increases by airlines), visa regulations, and temporary bans on travel from some countries.

The impact of travel restrictions will primarily affect services (defined in Table 2) and particular goods. The export of standardized products such as raw materials or manufactured goods require relatively little person-to-person interactions in the exporting and importing country as, typically, product specifications are clear and markets are transpar- 
Table 2: Impact of Travel Barriers on International Business, by Sector ${ }^{1}$

\begin{tabular}{|c|c|c|}
\hline & Examples & Impact of travel barriers (time to travel, costs of travel) \\
\hline $\begin{array}{l}\text { Goods with } \\
\text { services } \\
\text { requirements }\end{array}$ & $\begin{array}{l}\text { - Industrial engineer- } \\
\text { ing } \\
\text { - Engines for aircraft, } \\
\text { ships, or trains }\end{array}$ & Barriers to provision of supplementary/tied services may reduce goods exports. \\
\hline Most other goods & $\begin{array}{ll}\text { - } & \text { Food products } \\
\text { - } & \text { Consumer durables } \\
\text { - } & \text { Standardized inter- } \\
& \text { mediate goods }\end{array}$ & $\begin{array}{l}\text { Little effect on existing trade relations Barriers to sales representatives } \\
\text { travelling likely to inhibit development of new export relations. }\end{array}$ \\
\hline $\begin{array}{l}\text { Services, Mode } 1 \\
\text { (cross border } \\
\text { supply) }\end{array}$ & - Digital services & $\begin{array}{l}\text { Substitution of travel-dependent services likely to increase digital services, e.g., } \\
\text { in education or consultancy. }\end{array}$ \\
\hline $\begin{array}{l}\text { Services, Mode } 2 \\
\text { (consumption } \\
\text { abroad) }\end{array}$ & $\begin{array}{ll}\text { - } & \text { Tourism } \\
\text { - } & \text { Education }\end{array}$ & $\begin{array}{l}\text { Barriers to clients reaching service providers likely to reduce tourism and } \\
\text { international students. }\end{array}$ \\
\hline $\begin{array}{l}\text { Services, Mode } 3 \\
\text { (intra-firm } \\
\text { exchanges) }\end{array}$ & $\begin{array}{l}\text { Banks, insurance, fi- } \\
\text { nancial and business } \\
\text { professional services }\end{array}$ & $\begin{array}{l}\text { Reduced movement of people likely to change headquarters/subsidiaries } \\
\text { relationships, possibility towards more autonomy, but with ambiguous effect on } \\
\text { volume of services provided. }\end{array}$ \\
\hline $\begin{array}{l}\text { Services, Mode } 4 \\
\text { (presence of a } \\
\text { natural person) }\end{array}$ & $\begin{array}{l}\text { - Consultants } \\
\text { - Construction }\end{array}$ & Barriers to service providers reaching clients likely to reduce service exports. \\
\hline
\end{tabular}

1. Services MODES are based on WTO/GATS; https://www.wto.org/english/tratop_e/serv_e/gatsqa_e.htm. See also Coté, Estrin, \& Shapiro (2020)

ent. Thus, existing business relationships will likely not be substantially affected, though the establishment of new relationships will likely be inhibited by company representatives being unable to travel. In contrast, customized products, especially in business-to-business markets, are traded in smaller volumes and usually require personal interaction at the sale, delivery, or operation stage. For example, complex products need explanation; engineers may need to engage with their counterparts to customize products; and after-sales services may have to be delivered on site. Without the effective provision of the service, the value of the good would be reduced.

Travel barriers are of special concern to service industries, which are of increasing importance in the global economy notwithstanding their comparative neglect by IB scholars (e.g., Coté, Estrin, \& Shapiro, 2020). However, the impact varies by the type of service as suggested in Table 2 , with the largest negative short-run impact occurring where the consumer travels across the border. Examples include education and tourism. Other services that typically have relied on travel, and that will be affected in the short-run, include those services delivered through a physical presence (such as consulting) and those delivered within multinational enterprises such as financial or professional service providers, including engineers, accountants, and lawyers. In contrast cross-border digital services are not impeded to the same extent by physical distance and may in fact in some circumstance be facilitated by it.

The long-run effects of administrative barriers to travel depend on the degree to which novel forms of virtual communication may not only substitute for some activities traditionally done face to face, but also reduce the minimum scale for establishing an operation, and hence facilitate in- creases in the geographic scope of operations. Services involving information or digital data transfers are likely to increase during and after the pandemic, and will affect other services. Even services typically consumed abroad and therefore reliant on travel, such as education, will likely see an increase in digital and virtual delivery.

Even the relationships between headquarters and subsidiaries are likely to change. Travel restrictions limit visits by senior management from head office, which in turn is likely to slow the establishment of new subsidiaries, inhibit joint venture negotiations, and reduce the effectiveness of social mechanisms of governance of subsidiaries. In the longer run, these executive travels may be substituted by virtual communications that will in turn possibly alter the nature of subsidiary-headquarters relations. The net impact of issues such as subsidiary autonomy, however, depends on how the technology is deployed: easy availability of detailed performance data can be used for more centralized monitoring, or for empowering more localized decision marking.

\section{CONCLUSIONS}

Distance is a dynamic concept, and ought to be treated as such in teaching international business. As we have illustrated, the COVID-19 pandemic had an immediate effect on several aspects of distance, and is likely to trigger longerrun effects that are subject to substantial uncertainty. The combination of COVID-19 related policies with an already underlying trend toward growing national protectionist policies may change the future of globalization such that distance becomes both more important and less pre- 
dictable.

If distance is to be treated as a dynamic construct in IB strategy and teaching, then its application must incorporate both current and possible future assessments for each aspect of distance, and their possible interaction. Since distance is sensitive to circumstances, frameworks to analyse it should contain appropriate risk mitigation strategies. Multinational firms ought explicitly to consider the possible future path of distance patterns, and the sensitivity of distance to major global risks including national security, global warming and future pandemics in their strategy development. Moreover, country relationships previously characterized by low levels of distance may abruptly change; consider the possible contrasting effects of Brexit on Anglo-German and Anglo-Australian business relations. Relatively warm economic diplomacy relationships can also rapidly cool as in the international business links between China on the one hand, and the US or Australia on the other. Firms therefore need to become increasingly cogniscent of current diplomatic realities. Going forward, the analysis of distance needs to incorporate risks and risk mitigation strategies, such as the creation of buffer stocks and the pursuit of geographic diversification, to address situations where previously low levels of distance suddenly increase.

\section{ABOUT THE AUTHORS}

Christine Côté (C.Cote@lse.ac.uk; PhD, LSE) is a Senior Lecturer in Practice in the Department of Management at the London School of Economics and Political Science. Her research and teaching have focused on international trade and investment policy and the internationalization strategies of MNEs, particularly in emerging markets. Prior to academia she worked as an international trade negotiator with the Department of Foreign Affairs and International Trade Canada where she represented Canada in negotiations at the WTO, the OECD, and on bilateral trade and investment agreements. Her professional career also included time as a global strategy and policy consultant to governments in developed and emerging markets.

Saul Estrin (‥Estrin@1se.ac.uk; PhD, Sussex) is Professor of
Managerial Economics and Strategy in the Department of Management at LSE. He has published widely, with 15 research monographs and edited volumes and more than 120 papers on privatization, corporate governance and comparative/transition economics. He has publications in Quarterly Journal of Economics; Journal of Economic Literature; Journal of Management Studies; Strategic Management Journal; Journal of International Business Studies and Journal of World Business, He has worked in recent years on FDI entry mode; institutional theory, business groups, state ownership and governance.

Klaus Meyer (kmeyer@ivey.ca; PhD, London Business School) is a Professor of International Business at Ivey Business School, Canada. He previously served on the faculty of China Europe International Business School, University of Bath University of Reading and Copenhagen Business School. He is a leading scholar in the field of international business conducting research on the strategies of multinational enterprises (MNEs) in emerging economies. He published over 80 articles in leading scholarly journals and eight books, including the Oxford Handbook of Managing in Emerging Markets. He is a Fellow of the Academy of International Business and recipient of the JIBS Decade award.

Daniel M. Shapiro (daniel_shapiro@sfu.ca; PhD, Cornell) is Professor of Global Business Strategy and past Dean at the Beedie School of Business, Simon Fraser University. He has published five books and monographs and over 100 scholarly articles on international business and strategy, corporate ownership and governance, foreign investment and MNEs, industrial structure, and various aspects of public policy. His research has been published in Strategic Management Journal, Journal of International Business Studies, Academy of Management Journal, Journal of Management Studies, Journal of World Business, and International Journal of Industrial Organization, among others. He is AIB Educator of the Year 2014.

Submitted: August 26, 2020 EST, Accepted: November 20, 2020 EST

This is an open-access article distributed under the terms of the Creative Commons Attribution 4.0 International License (CCBY-4.0). View this license's legal deed at http://creativecommons.org/licenses/by/4.0 and legal code at http://creativecommons.org/licenses/by/4.0/legalcode for more information. 


\section{REFERENCES}

Brynjolfsson, E., Hui, X., \& Liu, M. 2018, August. Does Machine Translation Affect International Trade? Evidence from a Large Digital Platform. NBER Working Paper 24917.

Coté, C., Estrin, S., \& Shapiro, D. 2020. Expanding the international trade and investment policy agenda: The role of cities and services. Journal of International Business Policy, 3: 199-223.

Ghemawat, P. 2001. Distance still matters: The hard reality of global expansion. Harvard Business Review, 79(8): 137-147.
Kostova, T., Beugelsdijk, S., Scott, W. R., Kunst, V. E., Chua, C. H., et al. 2020. The construct of institutional distance through the lens of different institutional perspectives: Review, analysis, and recommendations. Journal of International Business Studies, 51(4): 467-497.

Reinhart, C., \& Reinhart, V. 2020. The pandemic depression: The global economy will never be the same. Foreign Affairs, Sept./Oct, 84-95.

UNCTAD. 2020, May. Investment policy responses to the covid-19 pandemic. Investment Policy Monitor. 